\title{
Nutritional awareness among pregnant women in Latvia
}

\author{
Marija Kolosova $^{1 *}$, Med. Anna Miskova ${ }^{2}$ \\ ${ }^{1}$ Department of Obstetrics and Gynecology, Riga Stradiňš University, Riga, Latvia \\ ${ }^{2}$ Department of Obstetrics and Gynecology, Riga Maternity Hospital, Riga, Latvia
}

Received: 08 May 2017

Accepted: 03 June 2017

\section{*Correspondence:}

Dr. Marija Kolosova,

E-mail: marija.kolosova@gmail.com

Copyright: ( $)$ the author(s), publisher and licensee Medip Academy. This is an open-access article distributed under the terms of the Creative Commons Attribution Non-Commercial License, which permits unrestricted non-commercial use, distribution, and reproduction in any medium, provided the original work is properly cited.

\begin{abstract}
Background: Women's eating habits affect not only the course of pregnancy but also the later life's metabolic health of their off springs. In 2016 Latvian guidelines on healthy nutrition during preconception period, pregnancy and lactation were published. The aim of this study was to analyze the level of nutritional awareness among pregnant women in Latvia.

Methods: A descriptive cross-sectional study was carried out in Riga Maternity Hospital. 110 pregnant women receiving antenatal care participated in the survey.

Results: $64.5 \%$ of respondents received recommendations on proper nutrition from health care professionals during pregnancy, whereas only $20.9 \%$ were informed in the preconception period. $68.7 \%$ of participants, who received information about the principles of healthy nutrition, considered them to be sufficient. The majority of women got the recommendations from gynecologists-obstetricians- $4.9 \% .39 .1 \%$ of women used non-evidence-based sources when searching for the information about healthy nutrition. 34.5\% of all pregnant women had at least one health or social risk factor, which required individualized diet planning, however, $26.3 \%$ of them did not receive any recommendations at all. $28.7 \%$ of respondents started pregnancy with abnormal Body Mass Index (BMI).

Conclusions: Women should be advised to make diet corrections before pregnancy, therefore more consultations in preconception period are needed. Additional educational sources providing information about healthy nutrition should be considered.
\end{abstract}

Keywords: Educational intervention, Guidelines on healthy nutrition, Nutrition, Pregnancy

\section{INTRODUCTION}

Non-communicable diseases (NCD) have become the leading cause of death and invalidity worldwide. ${ }^{1,2} \mathrm{NCD}$ include such conditions as diabetes, cancer, cardiovascular and respiratory diseases. ${ }^{2}$ All these health problems have a common etiology- unhealthy lifestyle and potentially harmful habits. ${ }^{3}$ Low intake of vegetables and fruits, diets that are poor in fiber, increased consumption of salt, sugar and saturated fats, lack of physical activity, alcohol consumption and smoking are considered to be the main risk factors of NCD. ${ }^{3}$
In European Food and Nutrition Action Plan 2015-2020 was emphasized, that one of the key factors for reducing the incidence of NCD is providing healthy nutrition over the whole course of life, beginning with the earliest period possible. ${ }^{4}$ Recent studies have shown that woman's eating habits and metabolic state affects not only the course of pregnancy but also have an impact on fetal programming and offspring's health in later life. ${ }^{5}$ Such effect is explained by epigenetic mechanisms that alter gene expression during intrauterine development. ${ }^{5}$ This is the reason why in the context of global health more attention should be paid not only to the women's health 
and nutrition during pregnancy but also in the preconception period. ${ }^{6}$

Public education interventions and development of evidence-based guidelines play an important role in NCD prophylaxis. $^{6}$ In 2016 Latvian guidelines on healthy nutrition during preconception period, pregnancy and lactation were published. ${ }^{7}$ These guidelines define optimal micro- and macronutrient amounts, potentially harmful dietary substances and principles of nutritional safety. ${ }^{7}$ The aim of these recommendations is to reduce the spread of NCD by improving eating habits among women of reproductive age and by educating health care professionals about healthy nutrition aspects. ${ }^{7}$ To make public education more effective we need to analyze nutritional awareness level among pregnant women at present.

\section{METHODS}

This was a descriptive cross-sectional study, which was carried out in Riga Maternity hospital from November 2016 until February 2017. A survey was chosen as a data collection method. Questionnaires were designed in two formats: printed and online version. Printed versions were distributed in the outpatient and inpatient departments of Riga Maternity hospital. Online questionnaires were created using Google Forms program and were posted on social network websites. The study questionnaire was based on Latvian recommendations on healthy nutrition during preconception, pregnancy and postpartum periods published in 2016.

All in all, 162 pregnant women, who were receiving antenatal care, participated in the survey. 52 questionnaires were excluded from the study because of an incomplete filling out. Questionnaires were completed voluntarily and anonymously. To evaluate the necessity for individual dietary consultations survey participants were asked to provide information about the following risk factors: teenage pregnancy, Body Mass Index (BMI) $>30 \mathrm{~kg} / \mathrm{m}^{2}$, BMI $<18.5 \mathrm{~kg} / \mathrm{m}^{2}$, history of gastrointestinal diseases or surgeries, diets with the risk of insufficient nutrient intake, psychiatric diseases, substance abuse, multifetal pregnancy, subsequent pregnancy with an inter-pregnancy interval less than two years, low socioeconomic status.

The analysis was performed using IBM SPSS Statistics 24.0 software. The rates of risk factors and aspects of nutritional awareness were obtained from frequency tables. Confidence index of $95 \%$ was calculated with the modified Wald method.

\section{RESULTS}

Overall 110 questionnaires were included in the statistical analysis. Mean age of the respondents was 29.4 $(\mathrm{SD} \pm 5.1)$. The majority of them was in the age group of 25-29 years old (Table 1).

Table 1: Distribution among age groups.

\begin{tabular}{|llll|}
\hline $\begin{array}{l}\text { Age group } \\
\text { (years) }\end{array}$ & $\begin{array}{l}\text { Number } \\
(\mathrm{n})\end{array}$ & $\begin{array}{l}\text { Total numbers } \\
(\mathbf{N})\end{array}$ & $\begin{array}{l}\text { Number } \\
(\%)\end{array}$ \\
\hline $20-24$ & 18 & 110 & 16.4 \\
\hline $25-29$ & 43 & 110 & 39.1 \\
\hline $30-34$ & 27 & 110 & 24.5 \\
\hline $35-39$ & 21 & 110 & 19.1 \\
\hline $40-44$ & 1 & 110 & 0.9 \\
\hline
\end{tabular}

Out of 110 survey participants $44.5 \% \quad(n=49)$ were nulliparous and $55.5 \%(\mathrm{n}=61)$ have had deliveries before. Among all pregnant women $5.5 \%(n=6)$ were in the 1 st trimester of pregnancy, $23.6 \%(\mathrm{n}=26)$ in 2nd trimester and $70.9 \%(\mathrm{n}=78)$ in the 3rd trimester. All in all, 28.2\% $(\mathrm{n}=31$, CI 95\%, 20.6-37.3) women started pregnancy with an abnormal BMI (Table 2).

Table 2: Distribution of BMI at the beginning of pregnancy.

\begin{tabular}{|lllll|}
\hline BMI $\left(\mathrm{kg} / \mathrm{m}^{2}\right)$ & Number $(\mathrm{n})$ & Total numbers (n) & Number $(\%)$ & CI $95 \%$ \\
\hline$<18.50$ & 4 & 110 & 3.6 & $1.1-9.3$ \\
\hline $18.50-24.99$ & 79 & 110 & 71.8 & $62.8-79.4$ \\
\hline $25.00-29.99$ & 19 & 110 & 17.3 & $11.3-25.5$ \\
\hline$\geq 30.00$ & 8 & 110 & 7.3 & $3.5-13.9$ \\
\hline
\end{tabular}

Women were more often consulted about healthy nutrition during pregnancy: $64.5 \%(\mathrm{n}=71$, CI 95\%, 55.272.9). Only 20.9\% ( $n=23$, CI 95\%, 14.3-29.3) of respondents were informed about proper diet in preconception period. Among women, who received nutritional recommendations $68.7 \%(n=46, C I 95 \%, 56.8$ $78.5)$ considered them to be sufficient. In $33.6 \%$ of cases $(\mathrm{n}=37$, CI 95\%, 25.5-42.9) women did not receive any advice on healthy nutrition at all (Figure 1). In total $34.5 \%(n=38$, CI 95\%, 26.3-43.8) of study participants had at least one health or socioeconomic risk factor, because of which, according to the Latvian nutrition guidelines, they required individualized nutritional consulting (Table 3). 


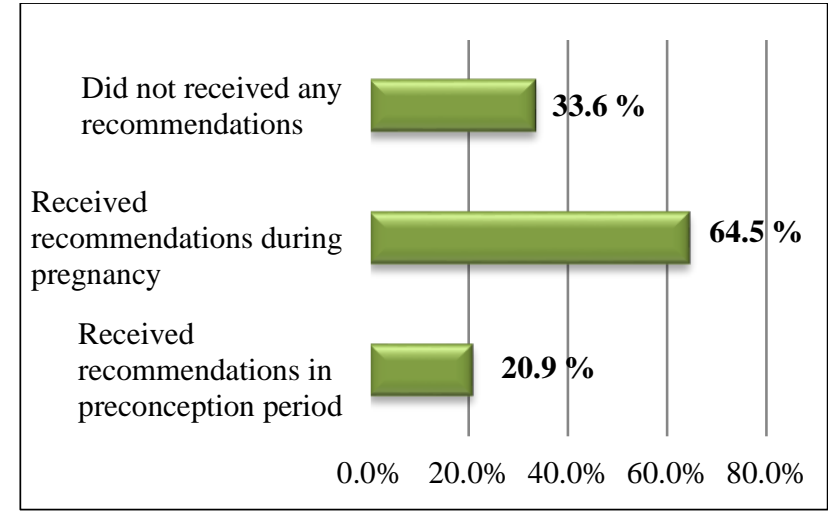

Figure 1: Rates of consultations given in preconception and pregnancy periods.

However, 10 people $(26.3 \%)$ in this group did not receive any recommendations during neither pregnancy nor preconception period. Among gastrointestinal diseases, history of gastritis or gastric ulcers was mentioned.

Cases of cholecystectomies and appendectomies were reported in the gastrointestinal surgery section. Since there was a lack of evidence that appendectomies can cause digestion problems in the future, these cases were excluded from statistical analysis. There were 2 women, who followed imbalanced diets in preconception period: vegetarianism and low-carbohydrate diet. Only one of them continued following the diet during pregnancy. The majority of women got recommendations from gynecologists-obstetricians- $84.9 \% \quad(n=62$, CI 95\%, 7.891.6), 16.4\% ( $\mathrm{n}=12$, CI 95\%, 9.5-26.3) were informed by general practitioners, $9.6 \%(\mathrm{n}=7$, CI 95\%, 4.5-18.8) by doctors of other specialties, $12.3 \%(n=9$, CI 95\%, 6.422.0) of respondents attended antenatal classes for parents to be, $6.8 \%(\mathrm{n}=5, \mathrm{CI} 95 \%, 2.6-15.4)$ were consulted by dietologists.

Table 3: Risk factors for insufficient nutrient intake.

\begin{tabular}{|lllll|}
\hline Risk factor & Number (n) & $\begin{array}{l}\text { Total } \\
\text { number }\end{array}$ & Number $(\%)$ & CI 95\% \\
\hline BMI $>30 \mathrm{~kg} / \mathrm{m}^{2}$ & 8 & 110 & 7.3 & $3.5-13.9$ \\
\hline $\mathrm{BMI}<18,5 \mathrm{~kg} / \mathrm{m}^{2}$ & 4 & 110 & 3.6 & $1.1-9.3$ \\
\hline Teenage pregnancy & 0 & 110 & 0 & - \\
\hline Gastrointestinal diseases & 8 & 110 & 7.3 & $3.5-13.9$ \\
\hline Gastrointestinal surgeries & 3 & 110 & 2.7 & $0.6-8.1$ \\
\hline Insufficient diet & 2 & 110 & 1.8 & $0.1-6.8$ \\
\hline Psychiatric diseases & 0 & 110 & 0 & - \\
\hline Substance abuse & 1 & 110 & 0.9 & $<0.01-5.5$ \\
\hline Low socioeconomic status & 1 & 110 & 0.9 & $<0.01-5.5$ \\
\hline Multifetal pregnancy & 3 & 110 & 2.7 & $0.6-8.1$ \\
\hline $\begin{array}{l}\text { Inter-pregnancy interval less than } \\
\text { two years }\end{array}$ & 14 & 58 & 24.1 & $13.8-36.2$ \\
\hline
\end{tabular}

$39.1 \%(\mathrm{n}=43$, CI $95 \%, 30.5-48.4)$ of women were looking for the information about healthy nutrition during pregnancy on the internet or in other sources (Figure 2).

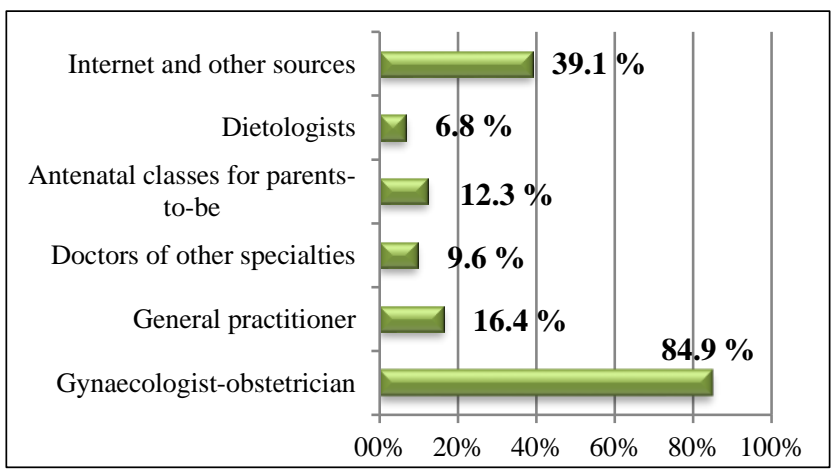

Figure 2: Consultation provider.

\section{DISCUSSION}

Results of this study showed that women received recommendations about healthy nutrition in pregnancy mostly from gynecologists and obstetricians. This fact once again proves the necessity to discuss the topic among these healthcare professionals in particular. Women usually received information about healthy diet principles only after conceiving.

Medical specialists should put a greater emphasis on nutritional consulting in preconception period and encourage women to plan their pregnancies. Many survey participants had one or more socioeconomic or healthrelated risk factors for insufficient nutrient intake. Healthcare professionals should take them into consideration before giving any recommendations. One 
of the most frequent risk factors was inadequate BMI at the beginning of pregnancy. The research of Luo et al. has pointed out that women, for whom an individual dietary plan was created depending on their BMI, medical history and the week of gestation, gained less weight during pregnancy comparing with women, who received standard antenatal care. ${ }^{8}$

Several studies proved a positive effect of nutritional consulting on maternal health and pregnancy outcomes. According to Girard et al. meta-analysis, educational interventions normalized weight gain during pregnancy, increased children's birth weight, as well as lowered the risk of developing anemia and premature delivery. ${ }^{9}$

Some of the studies included in this meta-analysis pointed out that women, who received dietary recommendations improved their eating habits. ${ }^{9}$ There was a tendency to increase vegetable consumption, to use additional micronutrients and to eat snacks between main meals. ${ }^{9}$

In the meta-analysis of Ota et al., apart from abovementioned advantages, was shown that pregnant women, who got advice on healthy diet principles from healthcare professionals, increased protein consumption. ${ }^{10}$ Other studies analyzed not only women's awareness level but also evaluated an impact of medical specialists training.

Malta et al non-randomized controlled trial demonstrated that women received recommendations about healthy lifestyle more often from those healthcare workers, who attended lectures and took part in workshops, where such topics as nutrition and physical activity during pregnancy were discussed. ${ }^{11}$

Not all survey respondents considered received nutritional recommendations to be sufficient and tried to get the information on their own, using the internet or other sources. That is why it is essential to consider additional public education tools, which would be based on Latvian guidelines for healthy nutrition. These information sources should be easily understandable and accessible for all women, independent of their education level or socioeconomic background.

The study of Agricola et al reported positive experience using online questionnaires and program, which generated an individual list of risk factors and lifestyle recommendations for women, who were planning to conceive in the near future. ${ }^{12}$

To educate society United States Department of Agriculture created an internet platform, where it is possible to get information about healthy nutrition and calculate individual nutrient needs. ${ }^{13}$ Such information sources are economically favorable and make it easier for healthcare professionals to spread evidence-based recommendations. The introduction of similar educational tools should be considered in Latvia.
Funding: No funding sources

Conflict of interest: None declared

Ethical approval: The study was approved by the Institutional Ethics Committee

\section{REFERENCES}

1. WHO. Global Health Observatory data repository: All NCDs, Deaths per 100 000; Data by country. Available at http://apps.who.int/gho/data/node.main.A863?lang=e n . Accessed 20 November 2016.

2. WHO. Global status report on noncommunicable diseases 2014. Available at http://www.who.int/nmh/publications/ncd-statusreport-2014/en/. Accessed 20 November 2016.

3. Hale WA, Joubert JD, Kalula S. Aging Populations and Chronic Illness. In: Markle WH, Fisher MA, Smego RA. Understanding Global Health. 2nd ed. New York: McGraw-Hill;2014. Available at http://accessmedicine.mhmedical.com.db.rsu.lv/cont ent.aspx ?bookid $=710 \&$ Sectionid $=46796917$.

Accessed 20 November 2016.

4. WHO. European Food and Nutrition Action Plan 2015-2020. Available at http://www.euro.who.int/_data/assets/pdf_file/0008/ 253727/64wd14e_FoodNutAP_140426.pdf.

Accessed 20 November 2016.

5. Smith CJ, Ryckman KK. Epigenetic and developmental influences on the risk of obesity, diabetes, and metabolic syndrome. Diabetes Metab Syndr Obestet. 2015;8:295-302.

6. WHO. Good Maternal Nutrition. The best start in life, 2016. Available at http://www.euro.who.int/_data/assets/pdf_file/0008/ 313667/Good-maternal-nutrition-The-best-start-inlife.pdf?ua=1. Accessed 20 November 2016.

7. Latvian guidelines on healthy nutrition during pregnancy. 2016. Available at: http://www.ginasoc.lv/kliniskas-rekomendacijas-2. Accessed 10 September 2016.

8. Luo XD, Dong X, Zhou J. Effects of nutritional management intervention on gestational weight gain and perinatal outcome. SMJ. 2014;35(10):1267-70.

9. Girard AW, Olude O. Nutrition Education and Counselling Provided during Pregnancy: Effects on Maternal, Neonatal and Child Health Outcomes. Pediatr Perinat Epidemiol. 2012;26:191-204.

10. Ota E, Hori H, Mori R, Tobe-Gai R, Farrar D. Antenatal dietary education and supplementation to increase energy and protein intake. Cochrane Database Sys Rev. 2015.

11. Malta MB, Carvalhaes MA, Takito MY, Tonete VL, Barros AJ, Parada CM et al. Educational intervention regarding diet and physical activity for pregnant women: changes in knowledge and practices among health professionals. BMC Pregnancy Childbirth. 2016;16:175.

12. Agricola E, Pandolfi E, Gonfiantini MV, Gesualdo F, Romano M, Carloni E, et al. A cohort study of a 
tailored web intervention for preconception care. BMC Med Inform Decis Mak. 2014;14:33.

13. United States Department of Agriculture. Choose My Plate.gov. Available at www.choosemyplate.gov. Accessed 20 November 2016.
Cite this article as: Kolosova M, Miskova MA. Nutritional awareness among pregnant women in Latvia. Int J Reprod Contracept Obstet Gynecol 2017;6:2711-5. 